\title{
DA ALMA E DAS LETRAS: A ELOQÜÊNCIA COMO PROJETO HUMANISTA*
}

\author{
Luis André Nepomuceno ${ }^{* *}$
}

\begin{abstract}
Resumo: No presente artigo, propõe-se uma análise da carta Fam. I 9 (dos Rerum familiarium libri), de Francesco Petrarca, que coloca em evidência algumas das considerações fundamentais dohumanista italiano sobreaarte da eloqüência; $e$ discute-se ainda a composição de alouns procedimentos utilizados por Petrarca na construção de uma relação entre a retórica e as virtudes do espirito.
\end{abstract}

Uma das epístolas mais notáveis e lembradas do $1^{0}$ livro das Cartas Familiares de Petrarca é, sem dúvida, a Fam. I 9, dedicada ao amigo Tommaso Caloiro ${ }^{1}$. E com justiça: o texto, embora curto (três páginas na famosa edição Le Familiari, da Edizione nazionale delle opere di Francesco Petrarca), é um belo exercício de eloqüência latina e um dos raros momentos em que Petrarca parece decidido a resolver um velho problema acerca de uma das temáticas que lhe são mais caras, a saber: a própria eloqüência. Pode soar estranho que um dos valores mais decisivos do projeto humanista tenha permanecido, de uma forma ou de outra, inconcluso na epistolografia e no programa tratadístico de Petrarca, mas fato é que o grande

- Texto recebido para publicação em agosto de 2005.

- Professor da UNIPAM - Centro Universitário de Patos de Minas.

1 Ofereço uma tradução integral da carta como anexo deste ensaio. 
difusor dos studia humanitatis, embora consciente de que o "falar bem" é uma virtude, jamais pontuou com exatidão em que consiste a natureza mais profícua dessa suposta virtude. Relutante em aceitar a eloquentia como valor fundamental à construção do caráter essencialmente humano, sobretudo numa dimensão cristã, Petrarca constrói-lhe elogios tortuosos, hesitando entre ímpetos diversos, sempre a lembrar que as virtudes da alma são mais dignificantes e verdadeiras que o domínio das letras. Se a carta Fam. I 9 não é exatamente uma grande exceção a essa tônica (nela Petrarca volta a diminuir a eloqüência em função da formação do espírito), pelo menos ali a eruditio lingue é abraçada e exaltada, em toda sua grandeza, como um valor indiscutível e quase intrínseco ao gênero humano. Daí ser possível encontrar nessa carta uma provável resposta a velhos dilemas postos pelo primeiro Humanismo, e quem sabe, resgatados por uma herança que se refletiu nas modernas reflexões da Psicolingüística e da Análise do Discurso: até que ponto a linguagem espelha a formação do indivíduo? Que importância tem a palavra na formação da alma?

Inserida entre outras 7 cartas dedicadas a Tommaso Caloiro no $1^{\circ}$ livro das Familiares, a Fam, I 9 salta às vistas como texto genuinamente literário, em que o exercício da epistolografia alcança o engenho da arte. Sem dúvida, tem ares de um Petrarca maduro, o que, aliás, fere o princípio cronológico pensado pelo autor, na arquitetura geral das cartas. $\mathrm{O} 1^{\circ}$ livro das Familiares, a julgar pelo que o próprio epistológrafo argumenta e quer fazer crer, teria sido escrito em fase de juventude, na década de 1330, quando de suas primeiras viagens e de seu primeiro convívio com os Colonna, em Avignon, à exceção da carta introdutória a Ludwig van Kempen, que ele admite ser de 1350 . Tommaso Caloiro, ou Tommaso da Messina, como é referido na carta, é amigo de 
juventude, dos tempos da Universidade de Bolonha (Petrarca a abandonara em 1326), e a escolha de seu nome para figurar em 7 das 12 cartas do $1^{\circ}$ livro das Familiares parece insinuar também uma coletânea de juventude. É o que se depreende, por exemplo, da carta Fam. I 2, em que o humanista "fabrica" admoestações retóricas ao jovem Caloiro, por causa de seu ávido desejo de fama e de glória, típicos arroubos juvenis. Bem, o companheiro de Bolonha morreria prematuramente em 1340 ou 41 (DOTTI, 1992:100 e 434), o que invalidaria em parte a hipótese de epístolas a ele escritas em épocas tardias, bem como deixaria em aberto um problema filológico de se esclarecer o estilo maduro em carta juvenil. Mas estou plenamente de acordo com Billanovich (1947:48), quando diz que as primeiras Familiares são componimenti inventati entre 1350 e 51, para dar sentido ao todo e coerência com as composições posteriores ${ }^{2}$. Corroboro a hipótese com um único exemplo, sutil, porém revelador: uma expressão como humanorum studiorum cura ("a diligência dos estudos humanísticos"), que se lê no último parágrafo da carta, evidencia um percurso de maturidade, a noção de um composto ou de uma totalidade, que Petrarca teria somente em tempos posteriores, possivelmente a partir de 1350, quando a idéia do Humanismo como revolução estética e ideológica já estava inteiramente pronta. A expectativa de que a humanorum studiorum cura pudesse servir de consolo aos mistérios da vida, conforme se lê na passagem, ainda não era visível na década de 1330 . Portanto, senão todas, pelo menos boa parte das cartas a Tommaso Caloiro são invenções da maturidade, inseridas no $1^{\circ}$ livro do epistolário como efeito retórico da arquitetura literária, o que significa que a Fam. I 9 (e

2 Tatham (1925-26), que traduziu para o inglês algumas das primeiras composições das Familiares, datou-as da década de 1330, até 1338, antes da morte de Caloiro. Para o problema, ver o esquema proposto por Wilkins, no seu Petrarch's correspondence (1960). 
não há dúvida de que ela esteja entre as invenções posteriores) jamais foi expedida ao amigo, já que era falecido, quando a carta veio a lume.

Das cartas a Tommaso Caloiro que compõem grande parte do livro I, seis delas estão em sequiência (cartas Fam. I 712), com dois trípticos identificados com temáticas específicas. Billanovich (1947:49-50) argumenta que as três primeiras (Fam. I 7-9) poderiam facilmente compor um "trattatello di retorica, snodato in due lezioni e introdotto da una prefazione polemica: 'contro senes dyaleticos', 'de inventione et ingenio', 'de studio eloquentia'", enquanto as três últimas poderiam sugerir um segundo tríptico de caráter moral. Se todos esses textos, como propõe o mesmo Billanovich, são composições tardias, possivelmente de 1350-51, o tríptico de temática retórica pode ter sido estimulado pela recente leitura que o humanista fizera da Institutio oratoria, de Quintiliano (a quem ele, então, não conhecia), por meio do códice Par. lat. 7720, presente de seu admirador florentino Lapo da Castiglionchio (BILLANOVICH, 1947:84 e 184): ainda que o imenso tratado de Quintiliano (que ao humanista chegou mutilado) ${ }^{3}$ não tenha tido impacto tão decisivo na obra de Petrarca, isso não o impediu, por exemplo, de incluir, entre suas cartas fictícias aos antigos prosadores e poetas da Antiguidade, uma em especial dedicada a Quintiliano (Fam. XXIV 7). Moderado em seus elogios, Petrarca louva-lhe o estilo correto e o entusiasmo

3 Apenas em 1416, um códice possivelmente alemão do texto completo da Institutio oratoria seria descoberto por Poggio Bracciolini, numa abadia suíça. Petrarca teve consciência da fragmentação do texto que chegou a ele, e esforçou-se, em comunhão com o círculo dos humanistas florentinos, por preencher as lacunas do textus mutilus (PENACCINI, in QUINTILIANO, 2001:LXXIV). Porém, decisiva foi a nova interpretação que deram Petrarca e os humanistas ao texto de Quintiliano que, apesar de multidisciplinar (ele atende a anseios retóricos, morais, pedagógicos, lingüísticos, judiciários), fora tido, até a Idade Média, como tratado moral, em detrimento de seu conteúdo predominantemente retórico. 
pela erudição, mas situa-o em posto menos glorioso que o de Cícero e Sêneca. De qualquer forma, o conjunto das epístolas do livro XXIV das Familiares, dedicados aos antiquis illustrioribus, e que em grande parte foi escrito à mesma época do tríptico a Tommaso Caloiro, é uma reflexão ampla sobre os conceitos de linguagem adotados por Petrarca: ali, o epistológrafo das Familiares consolida seu elogio aos grandes prosadores retóricos do passado (de Cícero e Asínio Polião), seus mestres de retórica, sobretudo na seqüência Fam. XXIV 3-9, em que a temática da eloqüência está presente.

No todo, a carta a Tommaso Caloiro, assim como aquelas dedicadas aos antigos retóricos da latinidade, tem efetivamente fumos de invenção, de tal forma a evidenciar uma negligência absoluta por seu interlocutor, a não ser que este lhe tivesse solicitado a temática anteriormente, o que parece improvável. O destinatário poderia ter sido qualquer outro, já que o texto, imbuído de intenções unicamente literárias, mais parece um tratado minúsculo sobre a eloqüência, em que quaisquer vestígios da relação de amizade entre os dois interlocutores se tornam inapreensíveis. Petrarca deveria estar escrevendo mais à posteridade do que ao próprio Caloiro, interlocutor fictício e idealizado, trazido à baila para as intenções retóricas do epistolário, pelas razões que comentamos.

Também, conforme já mencionado, a eloqüência encontra aqui um dos elogios mais incondicionais na obra de Petrarca, e é significativo que esteja logo no $1^{\circ}$ livro das Cartas Familiares: o autor quer deixar estampado um problema que, nem à custa de dramas e reflexões subjetivas, será resolvido por inteiro. Na Fam. I 9, o argumento é de que a linguagem (sermo) subordina-se ao espírito (animus), embora lhe revele o caráter, mas que não seja isso razão para o ser humano descuidar de sua eloquiência, pois que não há dúvida de que a palavra deve servir de auxílio aos outros. Antecipando um possível 
argumento contrário de seu interlocutor, o de que o exemplo da virtude deve dizer muito mais do que as palavras, Petrarca já antecipa igualmente uma resposta, de cunho retórico e quase religioso, dizendo que a palavra bem dita é fonte profunda de convencimento e razão de eternidade, instrumento de alcance para tempos e espaços infinitos. O fictício e idealizado Tommaso Caloiro intervem mais uma vez: a humanidade já não teria escrito, em tantos volumes, o suficiente para aquilo que é útil à construção de suas virtudes? Talvez num dos mais extraordinários elogios de Petrarca à eloqüuencia, a resposta vem em forma de sentença, a exemplo das belas construções retóricas de Cícero e Sêneca: "que corram mil anos; e que os séculos sucedam a outros séculos, a virtude jamais será suficientemente louvada, e jamais os ensinamentos sobre $o$ imenso amor de Deus e o ódio ao pecado irão bastar; jamais as mentes mais agudas irão encontrar obstáculos na busca das coisas novas". Por fim, ainda que outros argumentos contrários sejam virtualmente pensados, Petrarca termina com uma defesa definitiva da eloqüência: "Se dela não se tirar proveito algum para as razões acima, que seja estudada por ser 'ótima coisa' e 'utilíssima a nós mesmos"'.

Dificilmente Petrarca voltaria a definir suas idéias sobre a eloqüência, pelo menos não de forma tão sistematizada, resolvida e consciente. É certo que em cartas a Francesco Nelli, prior da Igreja dos Santos Apóstolos de Florença (a quem ele chamou de Simônides), novos elogios à eloqüência são trazidos à luz, porém nunca com a límpida clareza da Fam. I 9. O humanista conhecera o eclesiástico, na volta de uma de suas viagens a Roma, passando por Florença, em 1350, à mesma época em que conhecera todo o círculo de seus admiradores e futuros amigos da cidade toscana, incluindo os eruditos Zanobi da Strada e Boccaccio (TATHAM, 1925:422). A carta Fam. XII 5, por exemplo, a segunda das 29 cartas que 
Petrarca enviaria a Nelli (é o interlocutor com maior número de cartas), parece ser basicamente uma exaltação da amizade recentemente conquistada (o fervor é tão intenso que suponho que Petrarca tenha feito acréscimos posteriores na última versão) e da eloqüência em si que, embora seja imenso valor humano, não é capaz de expressar a riqueza que se esconde na alma. A eloqüência de Cícero estaria mais pura em seu espírito do que nos ouvidos de sua audiência, assim como a musa é mais grandiosa na inspiração de Virgílio do que em seus escritos. Em outras duas cartas, também das Familiares (Fam. I 3 e Fam. XIX 17), voltaria a insistir na relação entre a alma e as letras, sempre a evidenciar a submissão destas àquela e a pontuar, por meios termos, a necessidade da eloqüência intrínseca do homem. Uma anedota estampada na carta Fam. XVI 14, também a Nelli, revela que este sentira-se profundamente envergonhado por conta de um erro de latim num seu discurso, fato a que Petrarca se apega para elucidar o quanto os eruditos são mais fortemente ligados à linguagem e ao estilo do que às virtudes e à vida - argumento agostiniano, conforme veremos a seguir.

Enfim, o que parece diferenciar a carta Fam. I 9, em estudo, de outros textos petrarquianos sobre a linguagem, é sua intenção visível de tornar a eloqüência um instrumento de eficácia educativa na edificação das virtudes humanistas. Se Kristeller (1961) pensou o humanismo como um imenso sistema de reintegração dos valores humanos aos estudos (gramática, retórica, poesia, história e filosofia moral), em detrimento dos valores naturalistas dos escolásticos (cosmologia, natureza, universo), é certo que a Fam. I 9 atende legitimamente às intenções mais profundas da "filosofia" humanista, no sentido de trazer ao centro das discussões o "falar bem" a serviço das virtudes morais. A eloqüência, como lembrança das convicções de Cícero, Quintiliano e Sêneca, torna-se uma 
arte, ou antes, uma virtude, o que, em termos de uma história social da linguagem, deverá abrir as portas para a arte da conversação, tão celebrada pela Renascença. Afinal, a arte da conversação, derivada da eloqüência humanista, será uma das virtudes mais recorrentes nos manuais de civilidade do séc. 16, de que Castiglione, Della Casa e Stefano Guazzo foram os mais significativos representantes, para ficarmos somente na Itália (BURKE, 1995). Dificilmente também Petrarca voltaria a definir a eloqüência como instrumento educativo, sobretudo da forma tão bem resolvida como se vê na Fam. I 9, ainda que o "falar bem" seja sempre tido, em outros momentos de sua obra, como virtude louvável. Como ele diz na Fam. XVIII 8: a eloqüência de um amigo deve ser bem vinda, caso ele a tenha, assim como outras qualidades suas, não porque seja uma exigência de ouvidos melindrosos, mas porque o bom discurso pode refletir boas qualidades mentais.

Mas é curioso que Petrarca busque a perfeita expressão da linguagem e faça o discurso contrário, ou seja, o de que o caráter da alma é sempre mais definitivo que o domínio das letras na formação do indivíduo. Caso acreditasse nisso, o humanista não teria se tornado o poeta e epistológrafo mais eloqüente do fim da Idade Média. Mas há nele uma resistência em aceitar a retórica, ou o falar bem, como uma virtude última, como um fim em si mesmo. A eloqüência só é louvável, na medida em que está a serviço de outros fins, de natureza moral, primeiramente porque as virtudes do espírito lhe superam a grandeza, e segundo, porque a obsessão pela retórica é projeto de uma Antigüidade pagã, alheia às revelações do Cristianismo. Claro, Petrarca está no alvorecer da Idade Moderna, e não sabe ainda como lidar com universos tão distintos, como a espiritualidade e a estética, embora tenha intuições sobre como identificá-las. 
Essas lições de resistência à retórica vieram a Petrarca certamente por meio das leituras de santo Agostinho, seu filósofo predileto, eleito para acompanhá-lo nas confissões desenvolvidas no Secretum. No Livro I das célebres Confissões agostinianas, que trata da vida da infância aos 15 anos, o bispo de Hipona reflete sobre os valores pedagógicos de uma Antigüidade tardia, pontuando os elementos que compuseram sua formação educacional, ao mesmo tempo em que dispõe de meios críticos para avaliá-los. Polêmico para as futuras gerações humanistas, Agostinho expõe radicalmente as contradições de um sistema educacional fixado pelo universo clássico grecolatino, tendencioso à erudição fria e loquaz, e negligente de valores humanos e religiosos. É a inteligência desperdiçada em coisas vãs, é a eloqüência a serviço de inutilidades, a que Petrarca se referiria séculos depois. A mesma anedota relatada pelo humanista na carta Fam. XVI 14, sobre o erro de gramática do amigo Francesco Nelli, deve ter a bênção pedagógica das Confissões agostinianas, em passagens como esta: "como são diligentes os filhos dos homens em observar as regras convencionais da gramática herdadas daqueles mestres que os antecederam, e como são negligentes em relação ao pacto eterno de eterna salvação (...)" (AGOSTINHO, 2002: 39).

A leitura das Confissões deve estar entre os fatos de maior impacto no jovem Petrarca, que certamente conhecia o texto desde a primeira juventude, e é inevitável que certos conceitos agostinianos interfiram em suas reflexões sobre o projeto da eloqüência humanista. Afinal, o que fazer do imenso universo classicizante que se lhe oferecia aos olhos, quando o apelo moralista da Cristandade lhe pedia que a boca fosse silenciada em suas futilidades retóricas? Como lidar com. a poesia e outras vaidades da eruditio lingue, a que Agostinho chamava de "corruptoras"? Eram problemas que o humanista só pôde evidenciar em forma de contradições inevitáveis, 
em que a bela e sedutora eloqüência era exercitada à custa de um discurso contrário, que tendia às virtudes, consciente do papel moralizador que deve exercer a linguagem singela e alheia a ornamentos. Se Agostinho confessava sua paixão pelo Hortênsio de Cícero, por razões de conteúdo e não de estilo, era justo que o eloqüente e classicizante Petrarca revelasse sua profunda admiração por um Agostinho de estilo pobre e singelo, ex-professor de retórica que abandonava as futilidades do ornamento.

No curioso opúsculo De secreto conflictu curarum mearum, em síntese chamado Secretum, Petrarca expõe grande parte de todos esses conflitos interiores. Convencido a manter o livro em segredo (daí seu título), para ser lido pela posteridade, o poeta toscano, pelo menos nessa obra em especial, preferiu o diálogo aberto a evasivas, já que, numa conversa imaginária com santo Agostinho, as verdades incômodas afloravam como pontas agudas no coração. No opúsculo, cuja primeira redação deve datar de 1347, o Agostinho de Petrarca, por sua vez (e deve-se pensar nele como uma espécie de personagem), é cruel e perspicaz na busca de tais supostas verdades. Num de seus discursos do livro I, o santo iguala a eloqüência ao âmbito de outras riquezas, como o poder, a beleza e a fama, numa série de bens que, juntos, não definem a salvação da alma (PETRARCA, 1987:85). Em novo embate, agora do livro II, Agostinho, ou a "segunda voz" de Petrarca, volta a condenar a eloqüência como fim em si mesma, em discurso mais rígido e imperativo:

"é verdade que o aplauso dos ouvidos parece ser o prêmio não desprezível da eloqüência, mas se falta o aplauso do próprio orador, que satisfação pode oferecer a rigorosa aprovação do vulgo? Portanto, como poderá deleitar 
os outros com tua eloqüência, se antes não deleitaste a ti mesmo?" (PETRARCA, 1987:105-107).

E depois: "O que é afinal essa eloqüência tão limitada, tão débil, que nem consegue abraçar todos os argumentos, nem dominar aqueles que abraça?" (idem). Por se tratar de uma espécie de certame dialógico, em que ambos os interlocutores são manipulados pela consciência do próprio Petrarca, agora é o humanista a rejeitar os argumentos do outro, dizendo que jamais se vangloriara de sua eloqüência em favor de um desejo de fama. Pura mentira, é claro. E ele sabe disso. Mas é curiosa essa passagem que parece dar pistas insinuantes e profundas sobre o dilema da eloqüência, a que Petrarca se vira atado em mãos e pés. Mas uma leitura do Secretum é complicada demais para as intenções deste ensaio: basta pensarmos que, até por volta de 1347, data da primeira redação do texto, ou 1353-54, data da segunda redação, pelo menos intimamente, a eloquiência como virtude ainda era um problema irresoluto na consciência de Petrarca, que oscilava entre seu elogio e sua condenação. À mesma época da primeira redação do Secretum, na exortação final de seu tratado $D e$ vita solitaria, escrito na solidão da casa de campo de Vaucluse, deixará outras marcas de sua resistência à eloquiência:

"O aspecto exterior da eloqüência deleitada com a luminosidade das palavras, porém destituída doverdadeirolume do pensamento, embora acariciando longamente os ouvidos, não tranquiiliza a alma, nem conduz àquela suprema e estável doçura, àquela paz de espírito (a isso os homens insensatos $\mathrm{e}$ soberbos não dão importância) que não se 
alcança senão por meio da própria humildade de Cristo" (PETRARCA, 1987:565).

A eloqüência destituída de verdade moral voltaria a ser matéria de reflexões petrarquianas, na invectiva De sui ipsius et multorum ignorantia, quando um elogio da extraordinária eloqüêricia de Cícero faz revelar que as belas palavras do orador romano conviviam tristemente com equivocadas convicções religiosas (tolices, na visão de Petrarca), tendentes ao politeísmo da época ${ }^{4}$.

Por tudo isso, a carta Fam. I 9, como texto sistematizado e consciente sobre a eloqüência, é curiosamente ùm raro momento de proposta de soluções ao problema do "falar bem" como projeto humanista. Não há outra circunstância como esta, pelo menos nas cartas. Se a conflituosa relação entre forma e substância sempre encontrou claras convicções de que Petrarca insistiu no "ser bom" como fundamentalmente mais importante do que "ser douto" ou "ser eloqüente", é na carta Fam. I 9 que o humanista deixa patente toda a dimensão da palavra escrita como fonte de eternidade ${ }^{5}$, o que invalida as inúmeras críticas feitas ao Humanismo como império da forma sem conteúdo. É essa a tônica do De ignorantia, invectiva escrita na maturidade, em que Petrarca se defende das acusações de ignorância feitas por quatro estudantes de Veneza. Cínica e espirituosa é a idéia que nos sugere o invectivista, ao dizer

4 A crítica a Cícero no De ignorantia apenas corroborava uma crítica mais ampla, que apontava a Antigüidade como fonte insegura de verdades espirituais, muito embora Petrarca partilhasse com Cícero a opinião de que a eloqüência nada significa sem a revelação moral: "he [Petrarca] certainly does not believe that eloquence is a mere technique capable of moving in any direction. He agrees with Cicero that it must be united with wisdom, or truth" (TRINKAUS, 1995: vol. 1:p. 48).

5 Sobre essa questão, remeto o leitor ao ensaio "Petrarch: form or substance?", em WHITFIELD (1966:27-51). 
que qualquer velhinha devota entendia mais de felicidade do que Aristóteles.

Portanto, volto a dizer que se a Fam. I 9 não é exatamente uma exceção a esse discurso da "anti-eloquiência" eloqüente defendido por Petrarca, no todo de sua obra, é nela que a palavra (sermo) é reconhecida, primeiro, como fonte inesgotável de exaltação à virtude, e segundo, como elemento de alcance da eternidade, já que a dimensão desse alcance é sempre infinita. Na carta em questão, os receios de uma eloqüência perigosa não existem, o elogio da linguagem nasce espontâneo, sem interferências do problema pagão. Essa tentativa de conciliar a linguagem, e por extensão, a doutrina, com a natureza moral certamente deve ter sido estimulada por convicções idênticas encontradas no Pro Archia, de Cícero, texto que o humanista citara alguns anos antes, no seu Discurso da láurea (Collatio laureationis), pronunciado no dia do recebimento de seu prêmio literário. Cícero, assim como Agostinho séculos depois, embora desprovido das convicções espirituais e cristãs do santo, estava perfeitamente consciente dessa relação entre moral e linguagem e, como exemplo aos humanistas posteriores, preferiu a grandeza daquela aos apelos estéticos desta, sugerindo, no entanto, que a junção das duas coisas (os clamores cristãos ainda não the eram realidade) poderia realizar uma "rara excelência quase impossível de descrever". (CICERONE, 1997:22). Daí o seu ideal humano. Cícero tinha em mente, conforme suas próprias revelaçōes, o elogio dos grandes generais da república das gerações anteriores, homens de extraordinária cultura, temperança e moderação, como Cipião Africano (a quem Petrarca dedicaria seu poema África), Caio Lélio e Catão, personagens históricos que se tornariam lenda nos códices e manuscritos manejados pelos humanistas.

Em outros termos, já havia em Cícero um ideal de síntese entre moral e eloqüência que, para Petrarca e os 
humanistas, era passível de ser reconstruído, desde que se the modificassem certos traços de inadequação ao programa ético da Cristandade. Mas tal reconstrução, ainda que apenas no âmbito da eloquiência (valor caríssimo a Cícero), nunca esteve totalmente livre de contradições conscientes inevitáveis, o que torna a obra de Petrarca um curioso embate entre Cícero e Agostinho, entre os apelos da eloqüência e as exigências da moral, em suma, entre Antigüidade e Idade Média. Nesse sentido, e corroborando a idéia das relações conflituosas entre esses dois universos distintos, vale a pena lembrar uma passagem de Cassirer, ainda que seja longo o trecho:

"A vida e a filosofia de Petrarca movem-se constantemente ao redor desses dois focos, insistem na luta por um equilíbrio entre os postulados humanistas da Antigüidade e os religiosos da Idade Média. Mas Petrarca não consegue alcançar um ponto de repouso nesta luta, um equilíbrio interior entre essas tendências antagônicas. Todo o encanto e toda a vivacidade dos diálogos de Petrarca consistem muito mais no fato de eles nos colocarem no centro mesmo dessa luta; de eles, incessante e infatigavelmente, entregarem o Eu ao sabor de forças espirituais antagônicas. O mundo interior de Petrarca permanece dividido entre Cícero e Santo Agostinho. Dessa forma, ele tem de rejeitar, de um lado, aquilo a que visa, de outro; tem de depreciar, do ponto de vista religioso, aquilo que para ele constitui o conteúdo e o valor espiritual da vida. Todo ideal humanista mundano - glória, beleza, amor -, aos quais ele se 
encontra ligado pelas fibras de seu Eu, não escapam desse veredito. Mas justamente disso resulta esse desequilíbrio do Eu espiritual, essa enfermidade da alma que Petrarca descreveu em seu diálogo De secreto conflictu curarum mearum, sua obra mais pessoal e mais profunda" (CASSIRER, 2001:63).

Se a carta Fam I 9 explicita legítimos elogios à eloquiência como valor ou virtude do projeto humanista, é certo que Petrarca haveria de se propor a encontrar não apenas um ponto de identificação entre esta e a moral, ou seja, entre a moral da alma e as letras, mas sobretudo um elemento que caracterizasse e pontuasse a natureza dessa eloqüência com propósitos morais. Suas infindáveis críticas ao estilo empolado e friamente dialético dos filósofos escolásticos medievais poderiam fazer supor uma proximidade íntima com a linguagem sugerida por Sêneca, especialmente em suas Cartas a Lucílio. Afinal, é ali - muito mais do que nos tratados de eloqüência de Cícero - que se propõe uma identificação estreita e profunda entre o caráter da linguagem e os apelos da moralidade estóica.

Sêneca jamais escreveu um tratado de eloqüência, apesar de ter-se formado advogado e se envolvido diretamente com estudos de gramática, mas uma verdadeira "teoria da linguagem" não sistematizada aflora de suas Cartas a Lucílio, embora de maneira fragmentada e pouco seqüencial, o suficiente, porém, para compor um arcabouço teórico sobre aquilo que o filósofo latino pensa sobre os efeitos da linguagem na formação do caráter. Se Sêneca parece merecer um papel menos decisivo no epistolário de Petrarca (é o próprio autor que nos convence da influência mais substancial deCícero), não vejo razões para não julgar meramente retóricas as considerações 
do humanista italiano. Cícero ofereceu a Petrarca instrumentos retóricos grandiloqüentes para a composição de uma linguagem amplificada - amplificatio (CICERONE, 2001:645). No entanto, é Sêneca quem the ensina o valor da eloqüência comedida, associada à filosofia moral, tendente a buscar recursos singelos de expressão e a evitar o estilo arrebatado e impetuoso, típico da dialética e dos jogos silogísticos, que não passam de estratégias falaciosas para confundir o raciocínio e, conseqüentemente, o caráter do interlocutor. Tais exercícios de retórica singela foram lembrados por Petrarca, por exemplo, em cartas como a curiosa Fam. XVIII 7, em que o autor mostrase profundamente tocado e deleitado com o estilo casual e apressado de seu interlocutor (no caso, Francesco Nelli), comparando sua carta a uma mulher bela flagrada de surpresa, com cabelos despenteados, seios entrevistos, pés nus, e roupas do dia-a-dia. Nada mais tipicamente senequiano. A efeito de aproximação dessas propostas, poderíamos lembrar, como exemplo, uma das considerações do estóico latino na carta 113 a Lucílio: "Assim como o luxo excessivo nos banquetes ou no modo de vestir é sintoma de uma sociedade doente, também o barroquismo de estilo, quando se generaliza, mostra que os espíritos estão decadentes - pois é do espírito que nascem as palavras!" (SÊNECA, 1991:632).

Mas isso já não é matéria que compete à carta Fam. I 9 que, longe de definir a natureza da linguagem e de oferecer possíveis recomendações a oradores, filósofos e epistológrafos, contenta-se com o elogio puro e simples da arte do "falar bem". Se há evidências profundamente senequianas em seu texto, deve-se entendê-las tão somente por uma relação estabelecida entre a retórica e o compromisso moral.

Poderá soar um tanto excessivo dizer que a carta Fam. I 9, em estudo, tenha encontrado soluções prontas ao problema da linguagem, de que Petrarca não dera notícia em outros 
textos seus. Anterior a outras produções em forma de carta ou tratado, como a redação definitiva do Secretum e do De vita solitaria (em que a eloqüência ainda assume ares de problema sem solução), a carta Fam I 9 não pode ser tida como decisão definitiva, ou resposta encontrada na maturidade, mas pode sugerir algo como uma justificativa consciente de sua própria obra. Por mais que nosso humanista tenha edificado sólida consciência de que "ser bom" é mais grandioso que "ser eloqüente" (é a conclusão do De ignorantia), sua obra literária - cartas, tratados, poesias - não é senão um exercício imenso do "falar bem", um esforço exaustivo de pura retórica, ainda que seja em favor do espírito e da moral. Sujeito vaidoso e presunçoso que era, Petrarca soube perfeitamente que, na qualidade de filósofo moral e poeta, a eloqüência era-lhe exercício de primeira grandeza, trabalho diuturno, atividade de uma vida. Claro, um texto de três páginas, como a carta que analisamos, não pode dar conta de soluções imediatas, sobretudo mediante uma imensa obra latina, como foi a de Petrarca, mas pode dar pistas de que o confronto entre a eloqüência latina e a espiritualidade moral cristã era apenas um artifício retórico do humanista para envolver seus leitores num embaraço que haveria de ter um desenlace nas gerações futuras. Afinal, conforme ele mesmo sugere, ainda que a eloqüência não nos sirva de qualquer utilidade moral, será sempre fructuosissimum studium. Mesmo dizendo o contrário, Petrarca parecia já intuir que era possível conciliar as duas coisas. Era o trabalho da retórica, à custa de um discurso da anti-retórica. Engenhosa contradição essa, às portas da modernidade.

\section{Anexo}

Para análise e tradução do texto da carta Fam. I9, segui a versão inglesa de Aldo Bernardo, na edição Letters on familiar matters 
I-VIII, vol. 1, cotejando-a com o original latino da Edizione nazionale delle opere di Francesco Petrarca. Para a tradução das citações petrarquianas ao longo deste ensaio, usei a edição Opere latine di Francesco Petrarca, da UTET.

\section{Carta Fam. I, 9}

\section{A Tommaso da Messina, sobre o estudo da eloqüência}

A preocupação da alma clama por um filósofo, enquanto o uso apropriado da linguagem requer um orador. Mas se desejamos, como se diz, retornar à terra e estar de boca em boca entre os homens, não devemos negligenciar nem uma coisa, nem outra. Da primeira falaremos depois, posto que é problema grave e complexo, mas de fertilíssimos frutos; por ora, para não fugir do tema a que me propus, te exorto e te encorajo a corrigir não apenas a vida e os costumes, que é o fim precípuo da virtude, mas a forma e os modos da linguagem, o que apenas o estudo de uma eloquiência bem regulada pode nos garantir. O discurso, na verdade, é o verdadeiro indicador de nossa alma, enquanto, por sua vez, a alma é a força moderadora do discurso. Um depende do outro: a primeira se esconde no peito; o outro sai a público. Um traz ornamento, à medida que sai da própria vontade; a outra, à medida que se dá à mostra, revela as qualidades interiores. Obedece-se à decisão de um, e se crê no testemunho da outra. Portanto, ambos devem ser providos, tanto a alma quanto o discurso, de modo que a alma seja justamente severa em relação ao discurso, e o discurso saiba mostrar toda a grandeza da alma, ainda que seja claro que onde há fineza de espírito não pode haver estupidez da expressão, assim como, ao contrário, um discurso jamais poderá ser digno se, à alma, falta a sua própria majestade. O que pode ser mais útil do que imergir- 
se completamente nas fontes ciceronianas, ou conhecer todos os escritores gregos e os nossos? Serás capaz de falar de forma ornada, graciosa, doce e sublime; mas certamente não serás capaz de exprimir gravidade, seriedade, sagacidade de pensamento ou - o mais importante - coerência de idéias. Porque se antes não tiveres conquistado firmeza de vontade - apenas o sábio pode alcançar esse equilíbrio - é inevitável que, na contradição dos sentimentos, estejam também em contradição os costumes e as palavras. Mas uma mente bem ordenada está sempre tranqüila e em calma, qual uma serenidade imóvel; sabe aquilo que quer, e aquilo que desejou nunca deixará de desejar, de tal forma que, mesmo que não a socorram os artifícios da arte oratória, ela encontrará em si vozes magníficas e austeras, perfeitamente correspondentes a si mesma. Não se pode, entretanto, negar que notáveis resultados podem ser realizados quando, tranqüilizados os sentimentos (em seu tumulto, jamais esperes algo de bom), põe-se ao estudo da eloqüência. Se acaso não precisássemos desta, e se pela sua própria capacidade, nosso ânimo pudesse silenciosamente revelar suas boas faculdades, sem o suporte das palavras, ainda assim deveríamos nos esforçar para o bem daqueles com quem vivemos, pois que não há dúvida de que nossa palavra poderia auxiliá-los em muita coisa.

Talvez desejes objetar-me: "como seria bem mais seguro para nós e bem mais eficaz para os outros persuadilos com o vivo exemplo de nossa virtude, de tal forma que, fascinados pela beleza desta, se sentissem impetuosamente impelidos a imitá-la! Os fatos se tornam melhores e os estímulos muito mais válidos na natureza das coisas do que nas palavras, e por essa via torna-se muito mais ágil, para nós, buscar os alcances mais altos da virtude". Não o contesto; efetivamente, já pudeste compreender meu pensamento, quando eu disse que, em primeiro lugar, deve-se pensar na 
educação da alma. Não foi por acaso que Juvenal disse: "Tu me deves, antes de tudo, as riquezas da alma", pois que estas não seriam as primeiras, se algo lhes fosse anteposto. Em verdade, o valor da eloqüência à formação da vida humana já foi demonstrado, seja pelas obras de muitos escritores, seja pela experiência quotidiana. Quantas pessoas já conhecemos, em nosso tempo, que não se sentiram tocadas de forma alguma por exemplos passados, mas que, subitamente, como que acordadas de um sono, deixaram uma vida desregrada para abraçar uma vida de grande simplicidade, por meio das palavras de outros! E não irei repetir aqui - pois que é famosa - a passagem do livro Da Invenção, de Cícero, em que ele debate longamente o argumento; ou a fábula de Orfeu e Anfião, em que se narra que, com o canto, um comoveu e conduziu para onde quis as bestas imensas, e o outro, as árvores e as plantas. Não recordaria tal fábula, se não mostrasse como, com a força de uma extraordinária palavra, um conseguiu levar gentileza e tolerância social a homens brutalmente toscos e instintivos, como animais, e o outro, a almas rústicas, duras e intratáveis como pedras. Acrescente-se ainda que, mediante o estudo da eloqüência, podemos ser úteis àqueles que vivem em países distantes, porque lá onde nossa presença não pode alcançar, alcançará a nossa voz. E de fato, o bem que faremos à posteridade pode ser estimado, quando consideramos o bem que nossos antepassados deixaram para nós.

Mas eis que objetas mais uma vez: "por que devemos nos esforçar tanto, se tudo aquilo que pode ser útil à humanidade já foi escrito há tantos anos, em tantos volumes, com maravilhosa eloqüência e por engenhos tão divinos?" Peço-te: deixa de lado essa preocupação, e não permitas que ela te conduza à preguiça. Esse temor já foi removido por alguns dos grandes autores antigos, e eu farei o mesmo por aqueles que virão depois de mim. Que corram mil anos, e que os séculos sucedam a 
outros séculos, a virtude jamais será suficientemente louvada, e jamais os ensinamentos sobre o imenso amor de Deus e o ódio ao pecado irão bastar; jamais as mentes mais agudas irão encontrar obstáculos na busca de coisas novas. Estejamos, portanto, tranqüilos: não estamos trabalhando inutilmente, nem inutilmente trabalharão aqueles que irão nascer depois de muitos séculos, com o próprio ocaso do mundo. Uma outra coisa, porém, se deve temer: que a humanidade tenha fim, antes que a diligência dos estudos humanísticos consiga penetrar os íntimos mistérios da verdade. Enfim, ainda que não nos estimulasse ao amor caritativo pelos homens, diria que o estudo da eloqüência deve ser sempre tido em consideração, porquanto é ótima coisa em si e utilíssima a nós mesmos. Que cada um julgue como queira; no que me diz respeito, não sei verdadeiramente como poder exprimir o conforto que, na solidão, me trazem algumas palavras notáveis e familiares que não apenas me nutrem o coração, mas que pronuncio a viva voz, e com as quais costumo acordar o ânimo adormecido; a doçura que experimento quando repito por vezes os escritos meus, por vezes, os de outros; ou a assistência que essa leitura sabe dar a minha alma oprimida por graves e acerbos danos. E sinto que meus próprios escritos me deram assistência, posto que são mais adequados a meus males, como a mão consciente do médico - ele mesmo doente - que toca justamente lá onde reside a dor: um resultado que eu jamais obteria, se essas palavras salutares não me tivessem lisonjeado os ouvidos e, impelindo-me a uma repetida leitura, com sua doçura inata, não estivessem pouco a pouco se escondendo em meu coração, penetrando-o profundamente com suas pontas secretas. Adeus.

$1^{\circ}$ de maio

Abstract: In questoarticolosi propone un'analisi dell'epistola Fam. I 9 (dei Rerum Familiarium Libri), di Francesco 
Petrarca, che mette in evidenza alcune delle considerazioni fondamentali dell'umanista italiano sull'arte dell'eloquenza; e si discute anche la composizione di procedimenti utilizzati da Petrarca nella costruzione di una relazione fra la retorica e le virtù dell'animo.

\section{Referências bibliográficas}

AGOSTINHO, Santo. Confissões. 15 ed. Trad. Maria Luiza J. Amarante. São Paulo: Paulus Editora, 2002 (Col. "Espiritualidade").

BILLANOVICH, Giuseppe. Petrarca letterato. I. Lo scrittoio del Petrarca. Roma: Edizioni di Storia e Letteratura, 1947.

BURKE, Peter. $A$ arte da conversação. Trad. Álvaro Luiz Hattnher. São Paulo: Editora da UNESP, 1995.

CASSIRER, Ernst. Individuo e cosmo na filosofia do Renascimento. Trad. João Azenha. São Paulo: Martins Fontes, 2001.

CICERONE, M. T. Dell'oratore. Introd. de Emmanuele Narducci. Milão: Rizzoli, 1994.

. Per un poeta: L'orazione pro Archia. Trad. Gavino Manca. Locarno: Armando Dadò Editore, 1997.

DOTTI, Ugo. Vita di Petrarca. 2 ed. Roma-Bari: Laterza \& figli, 1992.

KRISTELLER, Paul Oskar. Renaissance thought: the classic, scholastic, and humanist strains. Nova York: Harper and Row Publishers, 1961.

PETRARCA, Francesco. Le familiari. 2 ed. Ed. de Vittorio Rossi. Florença: Le Lettere, 1997 (Col. "Edizione nazionale delle opere di Francesco Petrarca"), 4 vols. 
. Opere Latine. Turim: UTET, 1987 (Col. "Classici Italiani"), 2 vols.

. Rerum familiarium libri: Letters on familiar matters. Vol. 1: I-VIII. Vol. 2: IX-XVI. Vol. 3: XVII-XXIV. Trad. Aldo Bernardo. Albany: State University of New York Press, 1975-1982.

QUINTILIANO. Institutio oratoria. Ed. de Adriano Penaccini. Turim: Einaudi, 2001 (2 vols.).

SÊNECA, Lúcio Aneu. Cartas a Lucilio. Trad., pref. e notas de J. A. Segurado e Campos. Lisboa: Fundação Calouste Gulbenkian, 1991.

TATHAM, Edward H. R. Francesco Petrarca: the first modern man of letters. His life and correspondence. A study of the early fourteenth century (1304-1347). Vol. 1: Early years and lyric poems. Vol. 2: Secluded study and public fame. Londres: The Sheldon Press, 1925-26.

TRINKAUS, Charles. In our image and likeness: humanity and divinity in Italian humanist thought. 2 ed. Notre Dame: University of Notre Dame Press, 1995 (2 vols.).

WHITFIELD, J.H. Petrarch and the Renascence. Nova York: Haskell House, 1966.

WILKINS, Ernest Hatch. Petrarch 's correspondence. Pádua: Editrice Antenore, 1960. 